\title{
Black Sea Synergy: Success or Failure for the European Union?
}

\author{
Hatice YAZGAN*
}

\begin{abstract}
Black Sea Region has been extensively on the agenda of the European Union (EU) since Romania and Bulgaria's membership in 2007. In 2008 the EU created "Black Sea Synergy" as a regional initiative in order to develop cooperation in the region in certain areas such as energy, transport and environment. Countries that take part in the Black Sea Synergy, Armenia, Azerbaijan, Georgia, Moldova, and Ukraine are also part of "Eastern Partnership" which is another initiative simultaneously established with "Black Sea Synergy" as a part of the wider policy "European Neighbourhood Policy" (ENP). Besides some EU member states, Turkey, an official candidate country to the EU since 1999, and Russia, a so-called strategic partner of the EU are significant actors in the "Black Sea Synergy" initiative although they are not included in ENP. The initiative comprises various common practices with similar initiatives of the EU, such as providing financial assistance, supporting economic development and stability as well as encouraging economic and democratic reforms. Although the EU attempts to take initiative in solving the conflicts and increase security in the region, it has significant deficiencies in conducting these policies as the literature indicates. This article aims to analyse the "Black Sea Synergy" in light of the recent developments regarding Turkey's deteriorating relations with the EU and Russia's annexation of Crimea and destabilization of Eastern Ukraine. The article attempts to answer "to what extent do these developments affect "Black Sea Synergy"? and argues that, although the "Black Sea Synergy" is an initiative mainly comprising technical projects in some key sectors, the crisis in Ukraine and the relations between Turkey and the EU have exacerbated the "challenge" confronted by the EU in terms of implementing the objectives of the initiative. Obviously the political development of the "Black Sea Synergy" continues to be dependent on reciprocal relations between the EU, Russia and Turkey in light of the current events. However the technical character of the Black Sea Synergy has the potential to maintain the contacts between the partners despite the political disagreements among them. All in all, a cooperative environment with Turkey and Russia will provide a common ground for achieving the EU's general objectives in the Black Sea region despite the prevalence of structural deficiencies of the $\mathrm{EU}$ as a foreign policy actor.
\end{abstract}

Keywords: Black Sea, Black Sea Synergy, EU, Russia, Turkey.

Assist. Prof., Çankırı Karatekin University, Department of International Relations, hyazgan@karatekin.edu.tr 


\title{
Karadeniz Sinerjisi: Avrupa Birliği için Bir Başarı mı, Başarısızlık mı?
}

\begin{abstract}
Öz
Karadeniz Bölgesi, Romanya ve Bulgaristan’ın 2007 yılında gerçekleşen üyeliği ile Avrupa Birliği’nin (AB) gündeminde yer almaya başlamıştır. 2008 yılında $\mathrm{AB}$, bölgede enerji, ulaştırma ve çevre gibi alanlarda işbirliğini geliştirmek amacıyla bölgesel bir girişim olarak "Karadeniz Sinerjisi”ni oluşturmuştur. Bu girişim içinde yer alan ülkelerden Ermenistan, Azerbaycan, Gürcistan, Moldova ve Ukrayna, aynı zamanda daha geniş bir politika olan Avrupa Komşuluk Politikasının bir parçası olan ve Karadeniz Sinerjisi ile aynı dönemlerde kurulan "Doğu Ortaklığı” üyesidir. Bazı AB üyesi ülkelerin de faaliyetlerine katıldığı girişimde yer alan diğer ülkeler, Avrupa Komşuluk Politikasına dâhil olmayan ve AB'ye 1999 yılından beri aday ülke olan Türkiye ve AB'nin stratejik ortağı olarak adlandırılan Rusya'dır. Bu girişim, kapsamındaki ülkelere mali yardım sağlanması, ekonomik kalkınmanın desteklenmesi, ekonomik ve demokratik reformların teșvik edilmesi gibi AB’nin benzer girişimleri ile ortak bir takım uygulamalara sahiptir. $A B$, her ne kadar bölgedeki mevcut çatışmaları çözmek için inisiyatif alsa ve güvenliği artırmaya çalışsa da, ilgili literatürün gösterdiği gibi söz konusu politikaları yürütmede önemli sorunlar yaşamaktadır. Bu makalenin amacı, Karadeniz Sinerjisi girişimi gelişmelerini, Türkiye’nin AB ile bozulan ilişkileri ve Rusya’nın Kırım’ı ilhakı ve Ukrayna’nın Doğusundaki kriz gibi yakın zamandaki gelişmeler ışığında değerlendirmektir. Makale, mevcut gelişmelerin "Karadeniz Sinerjisi”ni ne kadar etkileyeceği sorusuna cevap vermeye çalışmaktadır ve her ne kadar "Karadeniz Sinerjisi”" temelde belirli sektörlerde gerçekleștirilen teknik projeleri kapsayan bir girişim olsa da, Ukrayna krizi ve Türkiye-AB ilişkilerindeki sorunların, girişimin amaçlarını gerçekleştirmek bakımından $A B$ için önemli bir zorluk yarattığını öne sürmektedir. Mevcut durumda, Karadeniz Sinerjisi’nin siyasi gelişmeleri; AB, Rusya ve Türkiye arasındaki karşılıklı ilişkilere bağlı olmaya devam edecektir. Ancak yine de, "Karadeniz Sinerjisi”nin teknik projeleri kapsayan özelliği, taraflar arasındaki siyasi anlaşmazlıklara rağmen, ilişkilerini sürdürmeyi sağlama potansiyeline sahiptir. Sonuç olarak, AB’nin bir dış politika aktörü olarak yapısal eksikliklerine rağmen, Türkiye ve Rusya ile işbirliğine dayalı bir ortam oluşturulması, AB açısından Karadeniz Sinerjisinin genel amaçlarını gerçekleştirmek için ortak bir zemin sağlayacaktır.
\end{abstract}

Anahtar kelimeler: AB, Karadeniz, Karadeniz Sinerjisi, Rusya, Türkiye.

\section{Introduction}

Black Sea Region has been on the agenda of the European Union (EU) since Romania and Bulgaria's membership in 2007. In 2008 the EU created "Black Sea Synergy" as a regional initiative in order to develop cooperation in the region in certain areas such as energy, transport and environment. This initiative includes overlapping memberships and policies with some other EU related and international institutional structures. Countries that take part in the "Black Sea Synergy", Armenia, Azerbaijan, Georgia, Moldova, and Ukraine are also part of "Eastern Partnership" which is another initiative simultaneously established with "Black Sea Synergy" as a part of a wider policy "European Neighbourhood Policy". (ENP) Besides some EU member states, Turkey, an official candidate country to the EU since 1999, and Russia, a so-called strategic 
partner of the EU are significant actors in "Black Sea Synergy" initiative, although they are not included in ENP.

Russia and Turkey have distinctive places among the countries that take part in the initiative. The other countries that are also the members of "Eastern Partnership" have relatively stabilized relations with the EU to an extent. Even Ukraine and the EU have concluded an extensive Association Agreement called Deep and Comprehensive Free Trade Area (DCFTA). Besides, Moldova and Georgia have signed Association agreements with the EU in 2014. EU's relations with Azerbaijan and Armenia are not as progressed as the other countries. Armenia is the only country in the initiative that has closer relations with Russia compared to the others. In fact these countries' policies could be evaluated according to their positions between Russia and the EU. Thus the main confrontation is between Russia and the EU while analysing the developments regarding the initiative.

The other actor, Turkey has a complementary role for the EU policies in the region. Turkey is a regional actor that cannot be ignored and has an indispensable role for the stability of the region. EU accession process is the main anchor of Turkey's inclusion in the Black Sea Synergy initiative. Hence the deterioration of the relations between Turkey and the EU may have a direct impact on the "Black Sea Synergy" developments.

Therefore the EU's relations with the remaining two actors namely Russia and Turkey seem to be decisive on the future of the initiative and the recent developments regarding Russia and Turkey have given rise to reconsider the "Black Sea Synergy" developments.

Against this background, this article aims to analyse the current developments through "Black Sea Synergy" initiative and attempts to answer "to what extent do these developments affect "Black Sea Synergy"? First part is devoted to analyse the main structure of the initiative, its deficiencies and the main problems. In the second part, current developments regarding Russia and Turkey will be elaborated. The article will be concluded through analysing the possible results of these countries' current positions in context of "Black Sea Synergy".

\section{Black Sea Synergy: Aims and Consequences}

Black Sea region has a fragile security environment. Nagorno Karabagh issue, situation in Abkhazia and South Ossetia, Transnistria and most recently the situation in Ukraine are the most significant challenges confronted by the countries of the region. Despite this challenging environment, EU has initiated a policy that aims to cover the region from various aspects. In one sense, widening and deepening of the EU has enforced it to formulate this new policy.

"Black Sea Synergy" is a part of wider ENP and the other initiatives in the framework of ENP are "Union for Mediterranean" and "Eastern Partnership". The latter initiative has overlapping memberships with "Black Sea Synergy" except Belarus. The difference between "Eastern 
Partnership" and "Black Sea Synergy" is mainly regarding their relationship with the EU. "Eastern Partnership" aims to bring the partner countries closer to the EU while "Black Sea Synergy" just intends to foster "regional cooperation" in the Black Sea region (European Commission, 2010).

Russia is not a part of Eastern Partnership/ ENP; however this policy has direct implications with respect to the EU's relations with Russia.

Since ENP constitutes the main context in order to evaluate the other initiatives in the region, basic characteristics of this policy need to be assessed. As a part of ENP, "Black Sea Synergy" is an initiative open to "Black Sea States" and mainly aims to establish "partnerships" in "environment", "transport" and "energy" sectors. EU encourages the preparation of projects in these sectors supported by the EU funding and cooperates with the existing institutions in the region such as Black Sea Economic Cooperation Organisation (BSEC) (European Commission, 2010).

Although the enlargement policies of the EU and ENP - specifically the "Eastern Partnership"/"Black Sea Synergy" have some commonalities, they also have some different policy implications. EU was successful in transforming the Eastern Enlargement countries due to the favourable circumstances including the willingness of the accession countries and lack of a challenging power to the EU. However this was not the case for ENP. ENP countries were not equipped to adapt the EU and Russia has challenged the Union with respect to the common neighbours. Furthermore, the EU member states were internally divided and could not develop a coherent approach on the policy (Haukkala, 2016: 657- 659).

Although the EU has established various institutions and mechanisms through ENP, success of the policy remains contested. One of the contentious issues is the effectiveness of "conditionality" which refers to awarding incentives to these countries in return for the EU rule transfer. Without having a membership perspective, Partnership countries which have "hybrid regimes" like Georgia, achieved partial compliance with the EU conditionality. Bolkvadze relates this "selective conditionality" with the "hybrid regime survival strategies" of these countries (Bolkvadze, 2016: 409-410, 435).

Impact of the EU on the democratization process of the "Eastern Partnership" (and / or ENP) countries is contested as well. For example: lack of membership offer, prevalence of "diverse" and "competing international linkages" with regard to democracy promotion and salience of domestic circumstances as a "filter" to these linkages have designated the EU's impact on these countries (Sasse,2013:553). In a similar vein, as Christou argues, the EU was not effective in addressing the security problems of the "Eastern Partnership" (and/or ENP) countries emanating from the "weak governance", "frozen conflicts" and the other threats such as terrorism, illegal migration and etc. This ineffectiveness could be attributed to the deficiencies regarding the "capabilities" of the EU as a "security actor" (Christou, 2010:414).

According to Pridham, Eastern Partnership may be regarded as an outcome of the geopolitical conflict between Russia and the West, especially after Russia-Georgia war in 2008 (Pridham, 
2014:57). This conflict led the Eastern Partnership countries to take various positions between the EU and Russia and Eurasian Union emerged as a rival institution in the region.

The deficiencies of the ENP could also be applied to "Black Sea Synergy", as a regional initiative. In fact, Black Sea region has been defined as a source of "opportunities and challenges" by the EU with rich energy sources, market opportunities and transport routes as well as with frozen conflicts and threats such as illegal migration and environmental concerns. EU defines its policy in the region as to "stimulate economic and democratic reforms" and enhancing the "stability" in the region (Communication from the Commission, 2007:2).

"Black Sea Synergy" has been under regular review right after it has been launched. In the report that covers the period until 2014, it is emphasized that the EU continues this initiative with a "bottom up project development approach" in key sectors including maritime transport, energy, environment and tourism. Maintenance of "citizen to citizen contacts" is underlined despite the political developments in Crimea (European Commission, 2015:1). This report illustrates the developments in the sector partnerships that have been established within the initiative. Accordingly, workshops and conferences have been organized in order to look for opportunities for cooperation in maritime policy, collect "marine data", do the preparations for "maritime spatial planning" and enhance the existing measures for fishing quotas. Regarding the "environment", membership to the "Bucharest Convention" became an agenda item and the environmental monitoring projects have contributed to the sector developments. "Black Sea Synergy" comprises the projects on the development of infrastructure and modernisation of energy, transport and tourism sectors. Besides, the EU supports research and innovation through framework programmes and fosters cooperation in civil society. "Black Sea NGO Forum" is an initiative to be mentioned in this regard (European Commission, 2015:2-8). Despite these activities, "Black Sea Synergy" needs progress in some areas. The report underlines that the initiative requires concrete commitment of the countries in the region as well as increased participation of the stakeholders, coherence between various projects and cooperation in the collection of data concerning various sectors (European Commission, 2015:10).

\section{Relations with Russia}

Russia is definitely the most challenging actor regarding the EU policies in the neighbouring area. During the recent Nato Summit held in Warsaw on 8 July 2016, French President Francois Hollande expressed that “... Russia is not an adversary..., Russia is a partner". (Rettman, 2016) Despite these remarks, currently Russia is perceived as a direct challenge to European security. Thus, in response to the escalation of tension, EU Global Strategy released in June 2016 contains a remarkable concern for EU-Russia relations. This strategy in which "managing the relationship with Russia" is portrayed as a "key strategic challenge", clearly expresses the EU's concern for Russia's role in "destabilisation of Ukraine" and its "violation of international law". (European Union Global Strategy, 2016:33) 
In fact, despite the lack of a coherent approach among the member states, the EU has achieved to establish an institutional engagement with Russia to a considerable extent. "Partnership and Cooperation Agreement" constitutes the basis of the relations since 1997. This agreement regulates both the economic and political relations between the parties. Besides, the EU and Russia have designated some policy areas including security and research for further cooperation (known as "common spaces"). Parties established various mechanisms for dialogue among which "Partnership for Modernization" which aims to support civil society takes place (For more information about the history of relations, see European External Action Service, 2016). Despite this interaction, as Freire argues, Russia perceives the EU as a "limited player" in the neighbourhood region (Freire, 2014:370).

Nitoiu characterizes the 1990s and the beginning of 2000s as a cooperative period between the parties and identifies three main concerns both the EU and Russia have ignored which made the conflict inevitable. Firstly, the divergent views between the EU member states with respect to Russia, second, "geopolitical tension" emerged in order to exert influence in the Eastern neighbourhood area, and third, "clash of values and worldviews" between Russia and the EU. Accordingly, continuing to ignore these three concerns might give rise to other conflicts between the EU and Russia in various areas in the future (Nitoiu, 2016: 375-376, 385). Russia has exerted a heavy influence in the region and war in Georgia in 2008 and the current Ukraine crisis are two significant examples of this impact. In both of the conflicts, confrontation between Russia and the EU (or the West in general) has produced undeniable impacts for the countries in the region.

According to Gerrits \& Bader, after Russia-Georgia war in 2008, Russia has established various strong economic, social, intergovernmental and institutional ties or "linkages" with two regions, Abkhazia and South Ossetia and turned some of these "linkages" into "leverage". These ties and relations have enabled Russia to exert a heavy influence in these regions and they became dependent on Russia mostly in terms of economy, trade and financial assistance. These linkages between Russia and these regions have also prevented the resolution of the conflicts when the negligible EU influence is taken into consideration. (Gerrits \& Bader, 2016: 297-313).

Currently much attention has been devoted to Ukraine crisis both in academic and political circles. The crisis that took place in 2013 has multiple dimensions including the domestic considerations in Ukraine (Onuch \& Sasse, 2016: 558-559) well as the dynamics of the relations between Ukraine and Russia (Dragneva \& Wolczuk, 2016: 678-698), the EU and the wider West. The crisis has reached its peak when Ukraine President Yanukovich refused to conclude the agreement with the EU during the summit in Vilnius (2013). This agreement implied closer relations with the EU both in economic and political senses.

Subsequent developments have resulted with mass demonstrations in Maidan square of Kiev. These protests continued in different patterns with diverse range of protestors and Ukraine's European path was one of the themes of the protests (among others). (For an analysis of a survey conducted with protestors, see Onuch \& Sasse, 2016: 563,571). Overthrow of pro-Russian 
Yanukovich government led Russia to take a more aggressive stance through intervening Crimea (March 2014) and supporting separatists in Donbas. Ultimately, in April 2014, the separatists took the control of Donbas (the Donetsk and Luhansk Regions). Katchanovski's analysis of media reports and the other sources refers the perceived impact of both US and Russia respectively on Ukraine government and the separatists (Katchanovski, 2016: 2-10).

Russia's National Security Strategy issued on 31 December 2015 provides insights with regard to its approach to the West in general. The Strategy stresses challenges and threats instead of cooperation and encompasses a comprehensive national security understanding which has the main aim of protecting broad national interests. The Strategy displays Ukraine crisis as a “confrontation” between Russia and the West (Pynnöniemi \& Rácz, 2016:1-2).

Russia-Nato relations constitute a significant dimension of Russia's relations with the West which could be identified as a "zig-zag" relationship. Russia and Nato made a good start at the beginning of 1990's, however the relations deteriorated in various cases such as Nato operation in Kosovo, Nato enlargements, the Colour Revolutions in the region, Russia- Georgia war and finally Ukraine crisis. Despite facing common challenges and having established various institutions through the years, Nato has strongly reacted to Ukraine crisis and annexation of Crimea by Russia. As such, Nato took various measures against Russia, ranging from suspending cooperation with Russia to enhancing increasing military presence in vulnerable places. At the end, as Forsberg \& Herd note, "lack of trust" characterizes the current atmosphere and European norms and values remain as contentious issues between Russia and Nato (Forsberg \& Herd, 2015:41-57).

Haukkala describes the Ukraine crisis as a "symptom" rather than a "root cause" of the conflict between Russia and the EU (Haukkala, 2016:653) and argues that Ukraine crisis could be evaluated in a broader framework of relations between Russia and the EU in the post-Cold War period. Accordingly, post-Cold War years could be examined in three periods. First period of 1992-94 lasted with relatively optimist relations, whereas the second period (1994-2000) is characterized with some "troubles" and the third period, up to today, ended with the crisis in Ukraine and did not lead to establish a partnership between the EU and Russia (Haukkala, 2015:26).

EU has started to impose restrictive measures against Russia since the beginning of 2014. These measures, among which visa bans, asset freezes, economic sanctions regarding cooperation on specific sectors etc take place, have various effects both on the EU and Russia. When the EU prolonged the sanctions; Russia, in response, imposed import restrictions and sanctions to the EU products. (For the details of the sanctions, see Romanova, 2016: 774-796). Sanctions will be in force until Russia implements the provisions of Minsk agreement.

Despite the lack of a coherent approach between the EU members with respect to the EU-Russia relations, they achieved to enhance consensus during Ukraine crisis due to controversial MH17 Malaysia plane crash and Russia’s explicit support to Eastern Ukraine (Romanova, 2016:784). 
Accommodation of Russia in the post-Cold war European "security governance" based on OSCE norms and mainly shaped by Nato and the EU has already been a "challenge" before the Ukraine crisis. (Averre, 2016:703-704). Currently Ukraine crisis has exacerbated the Russian challenge for the EU and this challenge complicates to implement the objectives of "Black Sea Synergy"/ ENP for the EU.

\section{Turkey in the Black Sea Region}

Turkey is another significant regional partner of the EU in the "Black Sea Synergy" initiative. As mentioned in the 2007 communication of the European Commission, “...broad EU policy towards the region is already set out in the pre-accession strategy with Turkey, the ENP and the Strategic Partnership with Russia." (Communication from the Commission, 2007:3) Therefore, Turkey's inclusion in the initiative is mainly dependent on its EU pre-accession process. In other words, Turkey's EU process complements "Black Sea Synergy" and deterioration of Turkey's relations with the EU may also hamper the EU's "Black Sea Synergy"/ENP objectives.

Turkey's increasing interest in the Black Sea Region goes back to the end of Cold War. According to Aydın, Turkey was a "rising regional power" in the Black Sea region as a reflection of Turkey's search for alternative policy options (both in political and economic terms) in the post-Cold War circumstances. Thus BSEC became the main institutional structure for Turkey to pursue its interests. In fact this vision was an extension of President Özal's view of creating a regional cooperation structure comprising a wider area namely Euroasia. Although this view has not been realized, BSEC has played a role for former Soviet Union countries to conform to the global trade rules and increase economic cooperation between the parties. (Aydın, 2014: 383-386). On the other hand, Petriashvili argues that Turkey cannot be assumed as a "regional leader" in the Black Sea region. Accordingly, Turkey's interests are limited in the region such as preserving maritime security and it mainly aims to protect the Straits. Therefore Turkey does not promote "regional integration" in the Black Sea Region (Petriashvili, 2015: 106).

Turkey's approach towards the EU's "Black Sea Synergy" was supportive from the beginning and thus Turkey has strengthened the relations between BSEC and the EU. Turkey's supportive approach has continued even Turkey's relations with the EU was problematic at times (Aydin, 2014:386-387). In fact, the EU process has a significant impact on Turkey's policies towards the region. After Turkey is proclaimed as a candidate to the EU in 1999, Turkey's alignment with the EU policy was evident. Even in the period when the relations between Turkey and the EU have progressively deteriorated after 2006, Turkey’s position did not change (Üstün, 2010a: 238-239).

However, currently the EU-Turkey relations face one of the most severe crises. As a candidate country since 1999, the EU initiated accession negotiations with Turkey on October $3^{\text {rd }}, 2005$. However the relations have been deteriorated since 2005 and this period has been defined as "de-Europeanisation" by some scholars (Düzgit \& Kaliber, 2016:1-14). Although the relations have revived with the recent refugee agreement, structural problems continue to prevail such 
as Cyprus issue and implementation of Copenhagen (political) criteria and etc. Besides, mutual trust has been decreasing between the parties and public opinions of both sides have been loudly voicing their concerns regarding the accession process. Recent European Parliament decision on temporarily suspension of accession talks with Turkey indicates the crisis and therefore, deteriorating relations between Turkey and the EU have the risk of mitigating the opportunities for cooperation in the Black Sea region.

Relations between Russia and Turkey also play a considerable role in enhancing stability in the region and this factor influences the EU's policies. According to Aydin, "Turkey opposes the presence of external powers in the region, including the EU if their initiatives carry the danger of alienating Russia, and thereby creating instability in the region." (Aydın, 2014: 393). Therefore, Ukraine crisis which deepened the differences between EU and Russia carries the risk of Turkey's distancing itself from the EU's regional initiatives.

Turkey and Russia have established a close cooperation in the post-Cold War period due to a number of reasons such as disappearance of Soviet threat after the Cold War and Turkey's problems with the West. In fact Russian policies on Georgia, Syria and Crimea clearly contradict with Turkish foreign policy objectives in the region; however a considerable interdependence exists between these countries in the areas of economy and energy. (Aktürk, 2014:17-20). A severe crisis erupted in 2015 when a Russian warplane violated Turkey's airspace and thus shot down by Turkey. However recent moves of both sides for reconciliation refer to normalization of the relations to an extent.

As Aktürk argues "Turkey and Russia have been friends in times of weakness, while foes in times of strength" (Aktürk, 2014:21). Turkey's deteriorating relations with the EU and the crisis between Russia and the EU mainly due to Ukrainian crisis may have facilitated the cooperation between Turkey and Russia.

Nevertheless, mutual interests exist between Turkey and the EU regarding the region. Turkey has supported some EU funded projects such as Traceca-which aims to establish a transport corridor in the region and both parties have similar objectives in the region such as enhancing energy security. Üstün argues that the EU is an important factor in Turkish foreign policy due to the candidacy process and the EU cannot ignore Turkey taking into account its various ties with the its neighbourhood. Sharing the same neighbourhood, EU and Turkey have the common aim of ensuring stability in the region which require coordinated manner of both sides (Üstün, 2010b: 342-349).

\section{Conclusion}

As a part of ENP, "Black Sea Synergy" has been initiated as an ambitious initiative of the EU in order to enhance stability in the region. Black Sea region includes various challenges for the EU 
and the main objectives of the policy have not been met as some deficiencies of the EU policy taken into consideration.

Despite lacking a strategic vision, the EU formulated policies including institutions, financial programmes and projects for the region. According to Triantaphyllou, ENP countries followed "multi-vector" policies between Russia and the West and they have not been deeply committed to the EU norms. The other two "key stakeholders" in the Black Sea Region namely Russia and Turkey with "different set of value systems" are the other challenges for the EU. Triantaphyllou indicates the main challenge in order to enhance the stability in the region as the "tugs of war between Russia and the EU and to a lesser extent between the EU and Turkey". Thus the EU needs to build a "common narrative" to encompass the needs and demands of all parties. (Triantaphyllou, 2014: 286-295).

Currently the crisis in Ukraine and annexation of Crimea by Russia and deteriorating relations between Turkey and the EU refer to more challenging circumstances for the EU's Black Sea Synergy. Taking into account the relatively stabilized relations with the other Black Sea Synergy countries, future development of this initiative continues to be dependent on these two countries' relations with the EU in light of the current events.

Although the "Black Sea Synergy" is an initiative mainly comprising technical projects in some key sectors, the crisis in Ukraine and the relations between Turkey and the EU have exacerbated the "challenge" confronted by the EU in terms of implementing the objectives of the initiative. And obviously the political development of the "Black Sea Synergy" continues to be dependent on reciprocal relations between the EU, Russia and Turkey. However the technical character of the "Black Sea Synergy" has the potential to maintain the contacts between the partners despite the political disagreements among them.

The EU, Russia and Turkey have common interests in the region and they have extensive trade and energy links with each other. Regarding Turkey, general deterioration of the relations between Turkey and the EU may lead negative consequences on the other regional initiatives such as "Black Sea Synergy"/ENP. As Turkey's Black Sea policy mainly has an economic perspective (Aydın, 2014:387-388), EU's emphasis on political realm has a potential to complement Turkish policy in the region. Despite the prevalence of structural deficiencies of the EU as a foreign policy actor, a cooperative environment with Turkey and Russia will provide a common ground for achieving the EU's general objectives in Black Sea region. 


\section{References}

Aktürk, Ş. (2014) “Toward a Turkish-Russian Axis? Conflicts in Georgia, Syria and Ukraine, and Cooperation over Nuclear Energy", Insight Turkey, 16/4:13-22.

Averre, D. (2016) “The Ukraine Conflict: Russia’s Challenge to European Security Governance”, Europe-Asia Studies, 68(4): 699-725.

Aydın, M. (2014) "Turkish Policy towards the Wider Black Sea and the EU Connection", Journal of Balkan and Near Eastern Studies, 16(3):383-397.

Bolkvadze, K. (2016) "Cherry Picking EU Conditionality: Selective Compliance in Georgia’s Hybrid Regime”, Europe-Asia Studies, 68(3): 409-440.

Christou, G. (2010) "European Union security logics to the east: The European Neighbourhood Policy and the Eastern Partnership", European Security, 19(3):413-430.

Dragneva, R. \& Wolczuk, K. (2016) “Between Dependence and Integration: Ukraine’s Relations with Russia”, Europe-Asia Studies, 68(4):678-698.

Düzgit, Aydın S. \& Kaliber, A. (2016) "Encounters with Europe in an Era of Domestic and International Turmoil: Is Turkey a De-Europeanising Candidate Country?" South European Society and Politics, 21 (1): 1-14.

Forsberg, T. \& Herd, G. (2015) "Russia and NATO: From Windows of Opportunities to Closed Doors", Journal of Contemporary European Studies, 23(1):41-57.

Freire, M. R. (2014) “Russian Reactions towards EU-Black Sea Integration”, Journal of Balkan and Near Eastern Studies, 16 (3): 370-382.

Gerrits, A. W. M. \& Bader, M. (2016) "Russian patronage over Abkhazia and South Ossetia: implications for conflict resolution”, East European Politics, 32 (3): 297-313.

Haukkala, H. (2015) "From Cooperative to Contested Europe? The Conflict in Ukraine as a Culmination of a Long-Term Crisis in EU-Russia Relations", Journal of Contemporary European Studies, 23 (1): 25-40.

Haukkala, H. (2016) "A Perfect Storm; Or What Went Wrong and What Went Right for the EU in Ukraine", Europe-Asia Studies, 68 (4): 653-664.

Katchanovski, I. (2016) “The Separatist War in Donbas: A Violent Break-up of Ukraine?”, European Politics and Society, Online Journal:1-17.

Nitoiu, C. (2016) “Towards conflict or cooperation? The Ukraine crisis and EU-Russia relations", Southeast European and Black Sea Studies, 16 (3): 375-390.

Onuch, O. \& Sasse, G. (2016) “The Maidan in Movement: Diversity and the Cycles of Protest”, Europe-Asia Studies, 68(4): 556-587.

Petriashvili, S. (2015) "Where is the Black Sea Region in Turkey's Foreign Policy? Turkish Policy Quarterly, (Fall):106-112.

Pridham, G. (2014) "EU/Ukraine Relations and the Crisis with Russia, 2013-14: A Turning Point”, The International Spectator, 49(4): 53-61.

Pynnöniemi K. \& Rácz, A. (2016) “Threat perception affects operational doctrines”, FIIA Comment, The Finnish Institute of International Affairs, 2: 1-2.

Rettman, A. (2016) “Nato’s Russia Deterrent takes shape in Warsaw”, euobserver, 8 July, (Retrieved from: https://euobserver.com/foreign/134269, 8.8.2016).

Romanova, T, (2016) "Sanctions and the Future of EU-Russian Economic Relations", Europe-Asia Studies, 68 (4): 774-796. 
Sasse, G. (2013) "Linkages and the promotion of democracy: the EU's eastern neighbourhood", Democratization, 20 (4): 553-591.

Triantaphyllou, D. (2014) “The European Union and the Black Sea Region in Search of a Narrative or a New Paradigm", Journal of Balkan and Near Eastern Studies, 16(3) 286-299.

Üstün, Ç. (2010a) "Europeanization of foreign policy: the case of Turkish foreign policy towards the Black Sea region", Southeast European and Black Sea Studies, 10 (2): 225-242.

Üstün, Ç. (2010b) "EU and Turkish Neighbourhood Policies: Common Goals", Caucasian Review of International Affairs, 4(4), (autumn): 342-353.

\section{Web Resources and Official Documents}

Communication from the Commission to the Council and the European Parliament, (2007), "Black Sea Synergy - A New Regional Cooperation Initiative", Brussels. (Retrieved from: http://eeas.europa.eu/ archives/docs/enp/pdf/pdf/com07_160_en.pdf, 28.11.2016)

European Commission, Joint Staff Working Document (2015) "Black Sea Synergy: review of a regional cooperation initiative", Brussels. (Retrieved from: https://blacksea-horizon.eu/object/document/318/ attach/swd_2015_6_en.pdf, 28.11.2016)

European Commission, Press Release (2010) “Black Sea Synergy”, MEMO 10/78, Brussels. (Retrieved from: http://europa.eu/rapid/press-release_MEMO-10-78_en.htm?locale=en, 28.11.2016)

European External Action Service (2016), “The Russian Federation and the European Union”, https://eeas. europa.eu/delegations/russia/720/the-russian-federation-and-the-european-union-eu_en.

European Union Global Strategy (2016) "Shared Vision, Common Action: A Stronger Europe, A Global Strategy for the European Union's Foreign and Security Policy", Brussels. (Retrieved from: https:// europa.eu/globalstrategy/sites/globalstrategy/files/regions/files/eugs_review_web.pdf, 8.8. 2016) 